\title{
Gut microbiota: metabolic programmers as a lead for deciphering Ayurvedic pharmacokinetics
}

\author{
Anagha Ranade ${ }^{1}$, Shivani Gayakwad ${ }^{2}$, Shridhar Chougule ${ }^{2}$, Amey Shirolkar $^{3}$, \\ Sudesh Gaidhani ${ }^{4}$ and Sharad D. Pawar ${ }^{2, *}$ \\ ${ }^{1}$ Department of Ayurveda, and \\ ${ }^{2}$ Department of Pharmacology, Regional Ayurveda Institute for Fundamental Research, Pune 411038 , India \\ ${ }^{3}$ National Center for Cell Science, Pune 411007 , India \\ ${ }^{4}$ Central Council for Research in Ayurvedic Sciences, New Delhi 110 058, India
}

Gut microbiota has tremendous potential to influence human physiology in terms of health and disease. Factors like improper diet, lifestyle and stress contribute in development of dysbiosis. Ayurveda emphasizes on the importance of mahasrotasa (GIT system) and its homeostasis in maintenance of health. Pharmacokinetic principles of Ayurvedic pharmacology include Vipaka, commonly referred to as 'postdigestive irreversible process' which is closely associated with biotransformation of drugs caused by microbiota. There is evidence that the metabolism of polyphenols by the microbiota can influence their bioactivity. Consequently, inter-individual variation in microbial metabolism could have implications for health benefits of phytochemicals.

Keywords: Ayurveda, gut microbiota, pharmacokinetics, metabolic programmes.

As science advances, it opens an arena of novel leads in every field. The seers of Ayurveda have also quoted that in order to obtain thorough knowledge about one shastra (science), one needs to get acquainted with the other scientific literature which complements the former, one should be multifaceted in approach ${ }^{1}$.

With the advent of sophisticated instrumentation and omics approaches, microbiome is the most trending field that deals with the mechanism of equilibrium of our body. Recent studies have reported that a host of trillion microbes residing in our body govern the health status. It has been termed as the metabolic organ ${ }^{2}$, wherein the emphasis from the vital organs is now shifting to the gut, especially microflora of human gut for its essential role in the establishment of homeostasis. The microbial ecosystem of our gut comprises native species that are permanently found and those variable ones colonizing transitorily. The whole of microorganisms, their genes and metabolites are together termed as 'microbiome'.

*For correspondence. (e-mail: sd_pawar@yahoo.com)

\section{Significance of diet (ahara) and medicine} (aushadha) in Ayurveda

Ayurveda, the science of life, bestows certain unique principles in relation to the fundamentals of physiology of our body. Among the three pillars (trayopastambha) quoted by the seers, diet (ahara) is an essential component ${ }^{3}$. The significance of ahara has been quoted in four separate chapters (swasthya chatushka) of Charak Samhita ${ }^{4}$. Herein, they have emphasized that the overall maintenance of health is strongly associated with the quantity (matra) of diet (ahara $)^{5}$. The optimum food consumption further contributes in establishment of strength (bala), luster, radiance (varna), vitality and immunity (oja) ${ }^{6}$. Later, Charak adds that the quantity of ahara to be consumed is closely dependent upon bala (strength) of agni (metabolism) ${ }^{7}$.

The diet to be consumed and the status of agni (energy of metabolism) for its metabolism are interdependent. The strength of agni influences digestion in every season which has been given in the rutucharya (seasonal regimen). Hence, Acharyas have also suggested the diet regimen to be followed during each season (rutu) ${ }^{8}$.

The suitable food for consumption is that which without disturbing the homeostasis of tissues (dhatus) or dosha of the body gets digested as well as metabolized in appropriate time. Thus, it ought to possess individual variations due to variable digestive powers.

Ayurveda has classified the quantity of food (ahara matra) into two types, viz. sarvagraha and parigraha ${ }^{9}$. Sarvagraha refers to the amount as a whole (viz. all food constituents served in a meal together), whereas the individual component portions of the meal, viz. quantity of chapati, daal, etc. is parigraha. Ayurveda also emphasizes upon the pertinent consumption of shadrasa (diet possessing foods with six tastes). Any error in consumption of any individual component of ahara affects the health of tissues which results into ageing or pathology ${ }^{10}$.

Modern nutritionists have focused more on the proportions of carbohydrates, fats and proteins in diet, which comes under the parigraha aspect of matra. Ayurvedic 


\section{REVIEW ARTICLES}

approach to food and dietetics is different from the conventional Western approach. Charaka Samhita describes the eight ethics of ahara vidhi, i.e. (1) prakriti (nature of food substances), (2) karana (processing), (3) samyoga (combination), (4) rashi (proportion), (5) desha (region and climate), (6) kala (time), (7) upayogasamstha (rules of consumption), and (8) upayokta (the consumer) ${ }^{11}$.

\section{Digestion in ayurveda}

The avasthapaka (digestive process) basically consists of three phases according to Charaka, viz. Madhura, amla and $\mathrm{katu}^{12}$.

Madhura avasthapaka: It commences as soon as food comprising shadrasa comes in contact of bodhaka kapha (component for taste perception from salivary secretions) and continues up to amashaya (stomach). Here, some thin and frothy kapha (one of the three bodily doshas responsible for stability, unctuousness, lubrication, immunity and cohesion) is generated. It is often correlated with the breakdown of starch by salivary amylase and partial digestion in fundal part of stomach, where polysaccharides are broken down to monosaccharide.

Amla avasthapaka: Later, the partially digested (pakva and apakva) food comes in contact with amashaya (pyloric part of stomach) with the environment consisting of $\mathrm{HCl}$ that facilitates digestion of proteins and the resultant acidified chyme (vidagdha) is propelled into the duodenum ahead where achha pitta (bile) is produced.

Katu avasthapaka: When this food product reaches pakvashaya (large intestine), it gets further metabolized and hydrolysed by the agni (enzymes) and takes a bolus-form (paripindita) resulting in pungent taste. This stimulates vata dosha. This phase is often equated with the last stage of digestion occurring in the colon along with formation of indole, skatol and excretory products.

The avasthapaka thus can form a part of mechanical and biochemical digestion process in human physiology.

\section{Difference between vipaka and avasthapaka}

The vipaka (post-digestive metabolism) is the final transformation of food while avasthapaka is the initial phase. Vipaka commences only after the avasthapaka has ceased. This has been mentioned in the Chakrapani commentary ${ }^{12}$. The term 'bhinna kala' (time factor) denotes that these two stages are different. The actual vitiation of doshas and which in turn intimates the end of metabolism (rasa mala vivek) is termed vipaka. The factors that determine vipaka are dosha, mala (faecal matter, urine) and effect on shukra dhatu (tissue responsible for reproduction), which is the last tissue in sequential nutrition as per Ayurveda. Thus, vipaka is closely associated with secretion and absorption functions after the mechanical and chemical digestion. It is quoted as karma nishthaya, i.e. it manifests its properties at the end of complete digestion of food/drug ${ }^{13}$.

This again exhibits that vipaka is the ultimate transformation of food/drug (dravya) of particular perceptive attribute into final madhura, amla or katu tastes (rasas) ${ }^{14}$. Thus, it suggests that vipaka is an entity which comes into play after drug/food digestion for tissue nutrition or cellular nutrition.

Unlike conventional medicine, according to Ayurveda any dravya be it medicine (aushadha) or diet (ahara) will have to pass through vipaka for metabolism and manifestation of the action. The difference is of quantity and functions, where ahara is more in amount and results in nutrition, whereas medicines (aushadha) are administered in less amounts and have target actions but not nutritive as a whole to our body. Acharya Kashyapa has termed food (anna) as super medicine (mahabhaishyajya) ${ }^{15}$.

\section{Discussion}

Diet composition is a pivotal factor in modulating the gut microbial populations. Several studies have been performed to explore the inter-action between food and gut microbiota in relation to individual health status ${ }^{16}$. There are references in the treatise wherein a list of foods fit for daily consumption has been enlisted. Besides, the harmful effect of incompatible food (viruddha anna) has also been denoted which again relates with gut microbiota, i.e. incompatible food results in dysbiosis. This can be correlated with dhatvagnimandya that produces systemic effects and sets in pathologies of different diseases. Trillions of bacteria are distributed throughout the gastrointestinal tract from mouth to anus, which facilitate digestion and intestinal homeostasis. The components of diet are highly influential for colonization of microbiota. The variety of flavours (shadrasa) in a meal as stated before often point out the existence of many classes of bioactive compounds, that are necessary for constituting the needed consortium of microflora. Thus, the presence and quality of the consortium decides the fate of metabolism of the ingested food. The probable rationale behind ancient 'thali' diet prevalent in many parts of India has been delineated in a recent paper ${ }^{17}$. Similarly, in Ayurveda, the strength of agni has to be adjudicated on the basis of jarana shakti-capacity of digestion, that ultimately resides over the gut microbiota. Ayurveda considers the derangement of agni, i.e. its pachana karma (metabolism) to be the fundamental etiology for all anomalies. Similarly, unhealthy status of microbiota consortium due to wrong diet results in alteration of metabolism which thereby mirrors the physiopathology of nutritional disorder (closely associated with grahani). The anatomical distribution of gut microbiota resembles the mahasrotasa 
(gastrointestinal system in this context). The composition of gut microbiota depends on the functional role of each region of the gut in the digestion process. Thus, the region wise digestion closely relates avasthapaka, whereas the specialized and definitive metabolism of nutrients, viz. production of short chain fatty acids (SCFA), phenolic compounds, bioactives and alteration at metabolic level is vipaka.

\section{Role of gut microbiota on system physiology}

The gut microflora is referred to as a key endocrine organ, as it has significant impact on physiology and different human disease states which convert nutritional signals from environment that are hormone-like signals ${ }^{18}$. Gut microbiota aids in routine digestion and metabolizes the substrates producing cytokines, hormones, antigenic responses, activation of cascades, producing neuronal signals, etc. They also produce immune responses on various bodily systems of the host other than the gut.

\section{Ayurvedic vis-à-vis conventional ideology of the digestive system}

As discussed above, Ayurveda has its own unique way of stating metabolism of diet and drugs in form of vipaka. This metabolic energy is termed 'agni' in Ayurveda. Acharya Charak has stated the seat of agni to be grahani, and is said to be located above umbilical region ${ }^{19}$. This coincides with the major seat of gut microbiota. Jatharagni produces the sarakitta vibhajana of ahara (food) and helps in the assimilation of food. This prasada (essence of food) portion is then passed on to bhutagni for further metabolism ${ }^{20}$. This can be compared to various functions that gut microbiota perform in metabolism of carbohydrates, proteins, and fats and other nutrients in the body.

Gut microbiome is a key component in varied metabolic reactions such as digestion of carbohydrates, starch, sugars, oligosaccharides, proteins, non-digestible dietary fibre, transformation and degradation of the conjugated bile salts and oxalate-based complexes. The gut microbiota assist in the enzymatic reaction and stimulate production of various cytokines and other factors that can act either locally or systemically ${ }^{21}$. Commensals like Bacteroides thetaiotaomicron and Lactobacillus innocua produce antimicrobial proteins such as cathelicidins, (pro) defensins and C-type lectins ${ }^{21}$. The gut microbiota of healthy individual has high-energy metabolic markers such as pyruvic acid, citric acid, fumaric acid and malic $\operatorname{acid}^{21}$. The residual products of carbohydrate metabolism from the digestive system are further degraded by organisms (Bacteroides, Roseburia, Bifidobacterium, Fecalibacterium and Enterobacteria sps) producing SCFA like butyrate, propionate and acetate. These are proven to be high-energy yielding sources ${ }^{21}$ (Table 1). Bacteroides intestinalis, Bacteroides fragile and Escherichia coli process bile salts and convert them into secondary products such as deoxycholic and lithocolic acid in the gut, which in turn lead to lipid peroxidation and breakdown of steroids such as cholesterol ${ }^{21,22}$.

Various reports show the possible role of commensals, namely Oxalobacter formigenes, Lactobacillus species and Bifidobacterium species in reducing the chances of oxalate stones formation in the kidney ${ }^{21}$. Pancreatic lipase requires colipase for lipid digestion, commensal Bacteroides thetaiotaomicron alleviates the expression of colipase and thus enhances lipid hydrolysis ${ }^{23}$.

Ghrelin release is controlled by cholecystokinin (CKK), glucagon-like peptide-1 (GLP-1), peptide tyrosine tyrosine (PYY), which is eventually modulated by gut microbiota. High intake of lipids and proteins stimulates production of CKK, GLP-1 and PYY pancreatic polypeptides by few intestinal microorganisms. These peptides are responsible for deciding the meal size and long-term energy balance ${ }^{24}$. Gut microbiota metabolize bile salts by generating bile salt species that are distinct from those of the host ${ }^{25}$.

\section{Ayurvedic vis-à-vis conventional ideology of the respiratory system}

Each system in Ayurveda has been explained with the term 'srotasa', i.e. channels. In case of respiratory system, Pranavaha srotasa has been mentioned. Also, Charak has mentioned the role of 'mahasrotasa' which is gastrointestinal system as the main seat of prana related to respiratory system ${ }^{26}$.

The intestinal microbiota influences the respiratory microbiota by direct seeding of microbes from gut to the airway through the gut-lung axis or transferring the metabolites from the gut, short-chain fatty acids ${ }^{27}$. In the intestine, commensals help in production of mucous layer, antimicrobial proteins and IgA, which provides a physical barrier against pathogenic microbes ${ }^{21}$. It has been reported that Paneth cells maintain homeostasis with intestinal microbiota by producing antimicrobial peptides. Reg III (gamma) separates the intestinal and cell wall microbiota; it protects from Gram-positive bacteria which impact pulmonary immunity against fungal pathogens ${ }^{28}$. An experiment with germ free mice showed production of Th17 cells in the intestine after induction of commensal bacteria, which is important for various respiratory diseases ${ }^{29}$ (Table 2).

\section{Ayurvedic vis-à-vis conventional ideology of the cardiovascular system}

Heart in Ayurveda is considered under rasavaha (related to heart) and pranavaha srotasa (related to respiratory). It is also considered to be seat of psyche and oja (vitality), 
Table 1. Role of gut microbiota related to the human digestive system (after ref. 21)

\begin{tabular}{|c|c|}
\hline Organism & Function \\
\hline Firmicutes, Bacteroidetes, Proteobacteria and Actinobacteria & $\begin{array}{l}\text { Breaking down of dietary polysaccharides, competing with pathogens } \\
\text { and modulating host immune system }\end{array}$ \\
\hline $\begin{array}{l}\text { Bacteroides, Bifidobacterium, Fecalibacterium, Roseburia and } \\
\quad \text { Enterobacteria }\end{array}$ & $\begin{array}{l}\text { Synthesis of butyrate, propionate and acetate that reduce D-lactate } \\
\text { accumulation which is toxic to the host }\end{array}$ \\
\hline Bacteroides ruminococcus gnavus & Proinflammatory bacteria \\
\hline Bacteroides thetaiotaomicron & Upregulates lipid hydrolysis \\
\hline Bacteroides & Production of vitamins \\
\hline $\begin{array}{l}\text { Bifidobacterium, Bacteroides, Eubacterium, Lactobacillus, Clostridium, } \\
\text { Propionibacterium, Roseburia and Prevotella }\end{array}$ & $\begin{array}{l}\text { Ferments dietary oligosaccharides and stimulates production of } \\
\text { short chain fatty acids (SCFAs), therefore modifying the host immune } \\
\text { system to express IgG, act as a energy source and produce signalling } \\
\text { molecules }\end{array}$ \\
\hline
\end{tabular}

Table 2. Role of gut microbiota related to the human respiratory system

\begin{tabular}{lc}
\hline Organism & Function \\
\hline $\begin{array}{l}\text { Firmicutes and Bacteroidetes } \\
\begin{array}{l}\text { Lactobacillus rhamnosus, Bifidobacteriumlactis, and } \\
\text { Bifidobacterium breve, or an inactivated Mycobacterium } \\
\text { vaccae }\end{array}\end{array}$ & $\begin{array}{c}\text { Predominant phyla detected in the airways play an important role } \\
\text { in protection from pathogenic bacteria } \\
\text { Induces antigen-specific regulatory T-cells that help reduce } \\
\text { allergic responses }\end{array}$ \\
27eroidetes, Firmicutes & A-defensin 5 increases the balance of Bacteroidetes/Firmicutes \\
\hline
\end{tabular}

and any derangements in rasa dhatu leads to cardiovascular disease. In physiological aspects, it is clearly stated that for healthy functioning of the heart, an individual must consciously consumes diet favourable for heart and oja function. Thus, in Ayurveda each system has its connections ultimately with gut function ${ }^{30}$.

Tlaskalová-Hogenova et ll. $^{29}$ reported that atherosclerosis development was observed in germ free Apo-E deficient mice and not in conventionally reared Apo-E deficient (atherosclerosis model, apolipoprotein Edeficient mice). This denotes that commensals exhibit protective effect on mice health. The microbiota of conventional mice suppressed intestinal expression of fasting-induced adipocyte factor (Fiaf) and a circulating Lipoprotein lipase (LPL) inhibitor promote absorption of monosaccharides from gut lumen and storage of triglycerides in adipocytes ${ }^{31}$. The gut bacteria are known to synthesize estrogen, which leads to vasodilatation and protects the blood vessels from injury. This depicts their protective role in cardiovascular diseases ${ }^{32}$.

\section{Ayurvedic vis-à-vis conventional ideology of the nervous system}

All the functions of the nervous system resemble those of Vata (biophysical energy associated with bodily movements up to cellular level) in Ayurveda. Among five types of vata, samana vata is the enteric nervous system (ENS) which ultimately governs the entire gastrointestinal tract. In real sense, it is the sensory stimulus of ENS (samana vata) that is sent to central nervous system and resulting in vagal stimulation and gastrin feedback mechanism (prana vata) leading to the muscular movements, secretion of gastric juices (vyana vata) for digestion, absorption and discrimination ${ }^{33}$.

The gut-brain axis is a two-way communicating channel wherein the development and function of the nervous system is dependent on the gastrointestinal tract and vice versa. Muscularis macrophages (MM) regulate the intestinal motility; it communicates with enteric neurons by providing bone morphogenetic protein 2 (BMP2) signals and these neurons in return facilitates MM homeostasis by macrophage specific factor, viz. Colony stimulating factor 1 (CSF1). Thus, the signalling between neurons and GI is required for GI motility ${ }^{34}$. Mucosal enteric glial cells (EGCs) are regulated throughout the intestine by the microbial metabolites. Therefore changes in the functioning of glial cells relate to the gut-brain axis and dysbiosis in the gut $^{34}$. As discussed earlier, the neuronal peptides such as CKK, GLP-1 and PYY are stimulated by the gut microorganisms for expressing gut hormones (like ghrelin).

The gut-brain axis is responsible for the regulation of hypothalamic-pituitary-adrenal (HPA) affecting the behaviour of the host $\mathrm{t}^{35}$. The production of various neurotransmitters such as GABA, serotonin, dopamine and noradrenaline is also done by the commensal thereby regulating the mood, cognition, emotion, motility and various secretions ${ }^{36-38}$. Therefore, it can be stated that the central nervous system is controlled by the gut microbiota protecting it from various neurological diseases (Table 3).

\section{Ayurvedic vis-à-vis conventional ideology of the skeletal muscle system}

In Ayurveda, it is diet and successive products formed that are nutritive to tissues ${ }^{39}$. Thus, in case of muscular 
REVIEW ARTICLES

Table 3. Role of gut microbiota related to the central nervous system

\begin{tabular}{|c|c|c|}
\hline Organism & Function & Reference \\
\hline Lactococcus sp., Streptococcus, Morganella morganii, Hafnia alvei & Production of serotonin & 21 \\
\hline $\begin{array}{l}\text { Bacillus cereus, B. mycoides, Bacillus cereus, B. mycoides, B. subtilis, Proteus vulgaris, } \\
\text { Serratiamarcescens, S. aureus, E. coli, E. coli K-12, M. morganii (NCIMB, 10466), } \\
\text { K. pneumonia (NCIMB, 673), H. Alvei }\end{array}$ & Production of dopamine & 36 \\
\hline B. mycoides, B. subtilis, $P$. vulgaris, $S$. marcescens, E. coli $\mathrm{K}-12$ & Production of noradrenaline & 36 \\
\hline $\begin{array}{l}\text { L. brevis DPC6108, L. rhamnosus YS9, B. adolescentis DPC6044, B. dentium DPC6333, } \\
\text { B. dentium NFBC2243, B. infantis UCC } 35624\end{array}$ & Production of GABA & 37 \\
\hline L. plantarum & Production of acetylcholine & 38 \\
\hline $\begin{array}{l}\text { L. lactis subsp. cremoris (MG 1363) L. lactis subsp. lactis (IL1403) L. plantarum (FI8595) H. alvei } \\
\text { (NCIMB, 11999), S. thermophiles (NCFB2392), K. pneumoniae (NCIMB, 673), M. morganii } \\
\text { (NCIMB, 10466) }\end{array}$ & Production of histamine & 36 \\
\hline
\end{tabular}

Table 4. Role of gut microbiota related to the skeletal muscle system (after ref. 41)

\begin{tabular}{ll}
\hline Organism & \\
\hline Lactobacillus reuteri and F. prausnitzii & Preservation of muscle mass and reduced systemic inflammation \\
Bifidobacteria lactobacilli & Production of folate \\
Escherichia coli, Klebsiella & Production of glycine betaine \\
Propionibacteria, Lactobacillus reuteri & Production of vitamin B12 \\
Bacillus subtilis, Escherichia coli, Bifidobacteria & Production of riboflavin \\
\hline
\end{tabular}

physiology too, diet plays a major role. Malnutrition results in degenerative disorders, whereas over nutrition results in production of 'ama' contributing to rheumatic disorders $^{40}$.

The role of gut-muscle axis in the supply of nutrients to muscles and their development has been reported ${ }^{41}$. Urolithins are produced by few bacterial species, which are responsible for skeletal muscle cell preservation, mitochondrial biogenesis and its activity. SCFA, are involved in improving metabolic efficiency of myofibres and protecting muscle protein catabolism ${ }^{41}$. The gutmuscle axis has been found to be associated with various pathways leading to increasing the metabolic efficiency of myofibre ${ }^{42}$. There can be emergence of new therapies which can reduce muscle wasting and related diseases by inoculation of certain commensal in the host (Table 4).

\section{Ayurvedic vis-à-vis conventional ideology of the reproductive system}

In the description of healthy spermatogenesis and oogenesis, a role of Shardrasatmak ahara (diet comprising six rasas) has been given prime importance. Thus, proper vipaka can result into formation of respective healthy tissue. In order to have a normal and healthy conception, hita anna sevana (wholesome diet) has been specified in Charak Samhita ${ }^{43}$.

Hormone production in the reproductive system is different for the male and female, which is assisted by different gut microflora. Over the course of pregnancy, the gut microbiota protects the mother and the foetus by producing hormones and signals. The gut impacts the immune system and produces inflammation in the body required in the pregnancy for the protection and devel- opment of the foetus. Proteobacteria, Actinobacteria and Lactobacillus are found in abundance in faecal matter of pregnant women ${ }^{44}$. The estrogen produced by gut microbiota using dietary estrogens and precursors can reduce metabolic disease during post menopausal period, thereby coping up with the decreased estrogen levels ${ }^{45,46}$ (Table 5).

\section{Gut microbiota and its association with disease pathogenesis}

The efficiency of gut microbiota in safeguarding human well-being by means of different pathways of metabolism has led to development of numerous associated linkages with the progression of disease owing to dysbiosis ${ }^{47-49}$. The derangement of gut microbiota consortium has been attributed for development of various diseases as follows.

\section{Ayurvedic vis-à-vis conventional pathophysiology of obesity}

In Ayurveda, meda dhatu adipose tissue dysfunction due to improper agni (metabolic energy) has been delineated as a cause for sthaulya, i.e. obesity. The vicious circle of hunger to satiety has been linked in etiology of obesity. Excessive consumption of madhura (sweet), sneha (lipid), lack of exercise lead to sthaulya even in upcoming progeny. Even treatment peculiarly consists of dietary management along with lifestyle modification and cleansing therapies of gut, viz. vamana (induced emesis), virechan (induced purgation) and Basti (enema) $)^{50}$.

A potential connection between gut microbiome and development of an obese phenotype has been mentioned by Ley. A proportional decrease in Bacteroidetes with 
Table 5. Role of gut microbiota related to the reproductive system (after ref. 46)

\begin{tabular}{ll}
\hline Organism & \multicolumn{1}{c}{ Function } \\
\hline Clostridia sp., Non Clostridiale sp., Ruminococcaceae sp. & Production of estrogen \\
C. scindens & Production of androgen by onverting glucocorticoids to androgens \\
Prevotella intermedius & Metabolizes estradiol and progesterone and changes their expression \\
\hline
\end{tabular}

increase in relative loads of Firmicutes was found to be interrelated with the microbial population of obese mice. This was confirmed in a clinical dietary intervention assessment demonstrating that weight loss in obese individuals was due to increase in the relative proportions of Bacteroidetes. The microbial population within our intestine play a key role in obesity ${ }^{51}$. In spite of reports stating that these distinct microbial colonies increase energy harvest which contributes to obesity ${ }^{52}$, this has not been found to be totally imperative. It is therefore obvious that there can be multifactorial aspects of microbiota engaged in weight gain etiology and host metabolism. Following weight loss in human subjects, Ley $^{51}$ found a decline in the Firmicutes to Bacteroidetes ratio. Turnbaugh et al. ${ }^{52}$ demonstrated that the levels of Firmicutes stay unchanged with lower proportion of Bacteroidetes and increased loads of Actinobacteria in obese individuals. The magnitude of the ratio Firmicutes: Bacteroidetes in obesity, however, is still doubtful. Long-standing dietary habits with the constituting gut microbiota strongly influence the manifestation of lifestyle disorders. They set in chronic low-grade inflammatory processes in our body ${ }^{53}$.

\section{Ayurvedic vis-à-vis conventional pathophysiology of diabetes}

In Ayurveda, Madhumeha is often regarded to share pathogenesis and clinical implication with diabetes. Madhumeha is one of the types of prameha, wherein the pathological changes in normal urine have been observed $^{54}$. Even some pre-diabetic symptoms stress upon the characteristics of urine ${ }^{55}$. The pathogenesis of prameha as given by seers clearly indicate its close correlation with Mutravaha samsthana, i.e. urinary system ${ }^{55}$. In Ayurvedic physiology, main function of urine is kleda vahana ${ }^{56}$ (moisture components aroused due to imbalances in metabolism.) The genesis of urine in Ayurveda consists of its commencement in pakvashaya ${ }^{57}$ (part of colon), which is a unique feature after the assimilation of food occurs in alimentary canal. Ayurveda treatment regimens in diabetes strongly emphasize the establishment of homeostatic environment primely in the gut rightly by emesis and purgation therapies ${ }^{58}$. Also, prescriptions on dietary alterations along with exercise ${ }^{59}$ further highlight the utmost importance given to the gastrointestinal tract. If read in between the lines, we can analyse the significance that it bestows upon the metabolic equilibrium essential in curbing diabetes.
Type-2 diabetes (T2D) is a rampant global metabolic epidemic often termed as a silent killer. The association of gut microbial composition and progress of T2D are gradually being unveiled ${ }^{53}$. The translocation of microbial colonies from the gut to the surrounding tissues with lowgrade inflammation is considered to be the underlying mechanism for this disease ${ }^{60}$. Pedersen and other scientists highlighted that the human gut microbiome apparently impinge on insulin resistance coupled with disturbed metabolomics of serum. The contributing species that have been identified for the same are Prevotella copri and Bacteroides vulgates ${ }^{61}$. Complex gene-environment interactions can lead to obesity and its associated metabolic complications. Larsen et al. ${ }^{62}$ scientists employed 16S rRNA compositional sequencing in two groups; one of diabetics and other of healthy controls. It was observed that the proportions of clostridia class were reduced while the Bacteroidetes and Betaproteobacteria were enhanced in a group with T2D compared with control.

\section{Ayurvedic vis-à-vis conventional pathophysiology of liver diseases}

The etiological factors for liver disorders in Ayurveda have been faulty dietary habits, wrongly given emesis/purgation therapies results in (dhatu vaishamya) malfunctioning in tissue metabolism. These are termed to be santarpan janya (due to faulty lifestyle habits) disorders ${ }^{63}$. This can be well linked to dysbiosis. Management of these lifestyle disorders often include gut-cleansing therapies mentioned above, which probably alter the gut microbiota composition or formulations that target gut for amapchana (metabolizing harmful residue).

Evidence exhibits the close interlinks of gut microbiota and chronic liver diseases ${ }^{64}$. Factors, namely gut barrier integrity, immune responses of liver to factors derived from gut; potentially contribute to address solutions for chronic liver diseases. The domain of bile acid signalling has disclosed the concept of the dynamic and highly regulated gut: liver axis ${ }^{64}$. Recent facts depict that dysbiosis can lead to the phenomenon of non-alcoholic fatty liver disease (NAFLD) occurring as a sequel to obesity. Patients suffering from this disease have bacterial overgrowth located in small intestine. They also express deranged permeability of intestine that leads to shift of microbe derived products into the portal circulation ${ }^{64}$.

Interference of certain multi-protein structures marks the imbalance of Bacteroidetes: Firmicutes ratio resulting 
into hepatic steatosis and inflammatory processes. Alcoholic liver disease expresses similar symptoms proclaiming abundant colonies of Bacteroidetes and Akkermansia, but decreased proportions of Lactobacillus and other similar colonies. Of late, it was explored that patients diagnosed with primary sclerosing cholangitis have distinct gut microbiota $^{64}$, A recent study by Nicolas et al. ${ }^{65}$ documented that hepatic gluconeogenesis can be controlled by the gut microbiota. Use of probiotics induces hepatic gluconeogenesis.

\section{Ayurvedic vis-à-vis conventional pathophysiology of inflammatory bowel disease}

This can be correlated to 'pravahika' in Ayurveda. The management of pravahika totally consists of series of medicated enemas again targeting colon and some wholesome recipes suitable for gut health like medicated porridges and soups ${ }^{66}$.

Recent studies have demonstrated the relation among dysbiosis and gastrointestinal diseases ${ }^{64}$. Imperative changes have been recognized in the microbial population of patients with inflammatory bowel disease (IBD) compared to healthy controls. The ratio of Firmicutes/ Bacteroidetes was found to be two times greater than healthy controls in IBD patients ${ }^{21}$.

\section{Ayurvedic vis-à-vis conventional pathophysiology of cardiovascular diseases}

Excessive eating, faulty timings of diet, incompatible food ingestion, faulty dietary habits as well as suppression of natural urges lead to formation of ama. This in turn deranges the metabolism in gut and hence hampers healthy functioning of the successive rasa dhatu which causes cardiovascular disorders ${ }^{67}$.

Numerous facets of cardiovascular diseases comprise of plaque formation due to atherosclerotic changes followed by myocardial infarction and lastly heart failure. All of them are directly interlinked with dysbiosis. The metabolism of dietary phosphatidylcholine is a key example of the metabolic activity of gut microbiota on atherosclerosis development ${ }^{68}$.

During digestion, phosphatidylcholine which is found in primary sources like meat, fish and egg is hydrolysed into trimethylamine by gut bacteria. It is later oxidized in liver in the form of trimethylamine $\mathrm{N}$-oxide ${ }^{69}$.

\section{Ayurvedic vis-à-vis conventional pathophysiology of chronic obstructive pulmonary disease}

This is 'ama janya' disorder according to Ayurveda, which again proves its link to gut. Existing highthroughput next-generation sequencing (NGS) techniques have reported that the airways harbour varied microbial communities. Microbial diversity is copious in severe chronic obstructive pulmonary disease (COPD) $\operatorname{cases}^{70}$. Cameron et al. ${ }^{71}$ found remarkable changes in a COPD cohort summed with multiple features of COPD. Those comprised of specific exacerbation phenotypes, treatment differences and altered levels of key serum and sputum markers.

\section{Ayurvedic vis-à-vis conventional pathophysiology of nervous system disorders}

In Ayurveda, ahara is known to affect the properties of psyche satva, raja and tama. Accordingly, raja and tama are known to cause imbalance of doshas leading to psychiatric disorders ${ }^{72}$.

The gut microbiota critically contributes to activities of the central nervous system. These frequently encompass immunological, neural and endocrinal pathways. This also consists of direct interface between enteric neurons and gut microbiota. Besides this, synthesis of neurohormones like serotonin, dopamine, etc. with regulation of hypothalamo-pituitary axis are all attributed to gut microbial functions ${ }^{73}$.

Neuropsychiatric disorders often go hand in hand with certain modification in the gut microbial colonies. Examples include anxiety, autism ${ }^{74}$, bipolar disorder, chronic fatigue syndrome, major depressive disorder, stress and schizophrenia ${ }^{75}$. It is also interconnected to neurodegenerative diseases, viz. Parkinson's disease, Alzheimer's disease, dementia, and stroke $\mathrm{f}^{76,77}$.

\section{Ayurvedic vis-à-vis conventional pathophysiology of cancer}

In Ayurveda, cancer can be termed as the bad prognosis of any disease mentioned in classics related to the respective systems/ srotasa $^{78}$.

Latest studies suggest that perturbations in the gut microbial communities further add to tumorigenesis. The Gram-negative Fusobacterium nucleatum has been most strongly linked to colorectal cancer ${ }^{79}$. The growth in gastric cancers also has an alliance with microbiota. This depends on the concentration of $H$. pylori and the corresponding changes in other microbial communities in the gut $^{80}$. Likewise, distinct microbial communities are found in case of oesophageal cancer after dysbiosis. Pertaining to liver, it has been stated that patients with hepatocellular carcinoma show profuse quantities of $E$. coli in faeces, much higher than healthy controls. Some studies have also described that gut microbiota aids in genesis of pancreatic cancer by promoting inflammatory changes, activating the immune response and by disseminating cancer-associated inflammation ${ }^{81}$. 


\section{Drug metabolism by gut microbiota}

The liver is the chief organ in charge of executing biotransformation and drug metabolism. However, drug metabolism may also partly occur at the intestinal level, which aids to have significant effect on the drug efficacy and safety ${ }^{82}$.

Human gut microbiota influences the pharmacokinetics of many drugs, viz. chemotherapeutics, immunotherapies, anti-inflammatory and antimicrobial drugs and antiretroviral therapies. It is observed that microbiota augment or inhibit the desired therapeutic effect in case of these drugs. They carry out these processes by aiding biotransformation. Many factors, including gut transit time, host genotype, metabolic type, dietary intake and absorption influence microbial drug metabolism. Among them, reduction and hydrolysis occur frequently ${ }^{83}$.

The class of carbohydrates and proteins that are complex and hence tedious to digest form the major substrates at the disposal of the microbiota. These substrates undergo fermentation in the presence of microbiota, which results in the production of a range of metabolites, including SCFA, branched chain fatty acids, ammonia, amines and phenolic compounds. Gases, viz. hydrogen, methane and hydrogen sulphide are also produced. In addition, the role of intestinal microbiota is implicated in the production of vitamins and the activation or inactivation of isoflavanoids ${ }^{84}$.

Gut microbiota participate in drug metabolism in various ways

- They produce enzymes that degrade drugs directly.

- They compete with drugs over the metabolizing enzymes.

- They alter activity of host drug metabolizing enzymes.

- They produce enzyme-inducing metabolites that alter the drug metabolic activities or pathways ${ }^{85}$.

- The first reported example of drug metabolism by gut microbiota is that of azo reduction of orally administered prontosil and neoprontosil to sulphanilamide. This modification was the first known pro-drug activation by gut bacteria because metabolite sulphanilamide was found to have antibacterial effect ${ }^{86}$. In order to understand the role of the gut microbiota in drug metabolism, in vivo studies are crucial representing different reduction-oxidation status of the gut and liver $^{87}$.

One of the first acknowledged and studied interactions of intestinal bacteria with drugs is the anticoagulant therapy. The intestinal bacteria play a role in the synthesis of vitamin K. Broad spectrum antibiotics, by decreasing the population of bacterial flora in the gut, can lead to vitamin deficiency. This may consequently enhance the anti- coagulant therapy action causing clinically significant adverse events ${ }^{88}$.

It has been found that reduced numbers of gut microbiota by pre-treatment of antibiotics reduces acetaminophen metabolism in gut ${ }^{89}$. The pharmacokinetic alterations of amiodarone and its active metabolite by treatment with probiotics was witnessed which rendered significant changes in the pharmacological effect of amiodarone, making the active metabolite therapeutically more potent ${ }^{90}$. These are some of the positive pharmacological actions exhibited due to metabolism of drugs by the innate gut microbiota.

Some negative or adverse effects also have been reported, viz. alleviation of drug-induced enteropathy in case of diclofenac, indomethacin and ketoprofen ${ }^{91}$, via $\beta$ glucuronidase inhibition mechanism. More examples include reduction of nitrazepam by microbiota human intestinal tract to 7-aminonitrazepam, which is then further metabolized in the liver to metabolite 7-acetylaminonitrazepam which is teratogenic.

Gut microbiota show evidence of a noteworthy action on the metabolism of polyphenols ${ }^{92}$. The metabolism of chlorogenic acid, naringin, and rutin, representative bioactives of three common families, viz. hydroxycinnamates, flavanones and flavonols respectively was studied by Rechner et al..$^{93}$ using in vitro mixed culture model of the human microflora.

Some examples of the effect of gut microbiota on metabolism of certain medicinal plants are as follows.

\section{Yashtimadhu (Glycyrrhiza glabra)}

There is evidence which denotes that gut microbiota is responsible for conversion of glycyrrhizin to $18 \mathrm{~b}-$ glycyrrhetic acid completely ${ }^{94}$.

\section{Panax ginseng}

The gut microbiota is reported to metabolize orally administered ginsenoside $\mathrm{Rb} 1$ to bioactive compounds such as $20-\mathrm{O} \beta$-D-glucopyranosyl-20(S)-protopanaxadiol often known as compound $\mathrm{K}$. The same action is inhibited when performed after administration of antibiotics ${ }^{95}$.

\section{Pueraria species}

The effects of metabolites calycosin and daidzein are biologically superior to those of puerarin and daidzin, which are metabolized by gut microbiota ${ }^{96}$.

\section{Aloe vera}

Barbaloin, a C-glycoside present in aloe, is reported to be metabolized in human faecal suspensions to the deglycosylated aloe-emodinanthrone. It exerts cathartic effect which is not exhibited by barbeloin ${ }^{97}$. 


\section{Scutelleria baicalensis}

Microbiota hydrolyse baicalin to baicalein which increase its bioavailability. Some pharmacological properties of baicalein, viz. anti-inflammatory, cytotoxicity for cancerous cells, anti-angiogenic potential are more than baica$\operatorname{lin}^{98}$.

\section{Citrus fruits}

Rutin is a flavonoid glycoside found in many citrus fruits which is metabolized by the human intestinal microbiota into several metabolites, including quercetin-3-Oglucoside, quercetin, the aglycone and 3,4-dihydroxyphenylacetic acid ${ }^{99}$. Similarly, hesperidine present in the variety of orange is primarily metabolized by gut microbiota into hesperetin which in turn exhibits enhanced cytotoxic activity in cancerous cells ${ }^{100}$.

Naringenin from grapes metabolizing in naringin inhibits hydroxymethy lglutaryl-CoA (HMG-CoA) reductase. It also induces antioxidant enzymes, such as hepatic superoxide dismutase and glutathione peroxidase, which leads to reduction of hepatic cholesterol and lipid peroxidation $^{101}$

Therefore, gut microbiota initiated pharmacokinetics and toxicological changes of drugs should be considered in future studies. It is also essential to accomplish the exact characterization of metabolites produced by the gut microbiota because these differ from those produced by hepatic metabolism. Finally, regulation of the gut microbiota may be a good target for enhancing the pharmacological effects of drugs.

\section{Future scope}

In spite of such extensive research (both in vitro and in vivo) related to gut microbiota, there are still deficient data regarding the exact mechanism of action of medicinal plants and also dietary components. This is still a big question related to the collective fate of metabolism of diet along with drugs which are often consumed. It can pave the way to unveil the role of aahara (diet) and aushadha (medicine) abiding by the principles of pharamacodynamics and pharmacokinetics of dravya (drugs) in Ayurveda.

The different responses of drugs due to their varied metabolism by gut microbiota explain vividly the need to probe into the fundamental concept of agni, which in turn affects vipaka and its degrees. This ultimately reciprocates on drug utilization and excretion at biota level, which highlights the importance of sara (utilizing of necessary metabolites)-kitta vibhajan (elimination by converting into excretory products at minute level.)

Most studies focus on individual components/constituents may it be of drug or food interaction with indivi- dual microbial communities. However, the very focus of Ayurveda resides upon the doctrine of holistic approach. Study designs which consider interface between whole drugs and not the isolates and consortium of gut microbiota will help further discover the fundamentals of the Indian traditional system of medicine.

1. Acharya, J. T. (ed.), Sushruta samhita. Commentary by Dalhana. Sutrasthana, Chap 4, Verse 7, Chaukhambha Sanskrit Sansthan, Varanasi, 2010, p. 18.

2. Possemiers, S., Bolca, S., Verstraete, W. and Heyerick, A., The intestinal microbiome: a separate organ inside the body with the metabolic potential to influence the bioactivity of botanicals. Fitoterapia, 2011, 82(1), 53-66.

3. Acharya, J. T. (ed.), Charak Samhita with the Ayurved Dipika commentary, Sutrasthana, Chapter 11, Verse 35, Chaukhamba Krishnadas Academy, Varanasi, 2010, p. 74.

4. Acharya, J. T. (ed.), Charak Samhita with the Ayurved Dipika commentary, Sutrasthana, Chapter 30, Verse 36, Chaukhamba Krishnadas Academy, Varanasi, 2010, p. 190.

5. Acharya, J. T. (ed.), Charak Samhita with the Ayurved Dipika commentary, Vimanasthan, Chapter 2, Verse 4-6, Chaukhamba Krishnadas Academy, Varanasi, 2010, p. 238.

6. Dwivedi, L. (ed.), Charak Samhita, commentary of Chakrapani, Chikitsasthana, Chap 15, verse 5, Chaukhambha Prakashana, Varanasi, 2013, 1st edn, p. 510.

7. Dwivedi, L. (ed.), Charak Samhita, commentary of Chakrapani, Sutrasthana Chap 5, verse 3, Chaukhambha Prakashana, Varanasi, 2013, 1st edn, p. 127.

8. Acharya, J. T. (ed.), Charak Samhita with the Ayurved Dipika commentary, Sutrasthana, Chapter 6, Chaukhamba Krishnadas Academy, Varanasi, 2010, pp. 44-49.

9. Acharya, J. T. (ed.), Charak Samhita with the Ayurved Dipika commentary, Vimanasthan, Chapter 1, Verse 21(4), Chaukhamba Krishnadas Academy, Varanasi, 2010, pp. 235-236.

10. Acharya, J. T. (ed.), Charak Samhita with the Ayurved Dipika commentary, Sutrasthana, Chapter 29, verse 23, 24 and 42, Chaukhamba Krishnadas Academy, Varanasi, 2010, pp. 179181 .

11. Acharya, J. T. (ed.), Charak Samhita with the Ayurved Dipika commentary, Vimanasthan, Chapter 1, Verse 21, Chaukhamba Krishnadas Academy, Varanasi, 2010, p. 235.

12. Dwivedi, L. (ed.), Charak Samhita, commentary of Chakrapani. Chikitsasthana, Chap 15, verse 9-11, Chaukhambha Prakashana, Varanasi, 2013, 1st edn, p. 511.

13. Dwivedi, L. (ed.), Charak Samhita, commentary of Chakrapani, Sutrasthana, Chap 26, verse 66, Chaukhambha Prakashana, Varanasi, 2013, 1st edn, p. 499.

14. Paradkar, S. (ed.), Ashtanga Hridaya, Hemadry commentary, Sutrasthana, Chap 9, verse 20, Chaukhambha orientalia, Varanasi. 1982, 7 th edn.

15. Sharma, H. (ed.), Kashyapa Samhita, Khila Sthana, Chap 4, verse 6, Chaukhamba Sanskrit Sansthana, Varanasi, 2013, p 249.

16. Rajoka, M. S. R. et al., Interaction between diet composition and gut microbiota and its impact on gastrointestinal tract health. Food Sci. Hum. Wellness, 2017, 6, 121-130.

17. Kaitlyn, S., Rob, K., Sanivarapu, A., Shuji, O. and Jairam, K. P., Vanamala, ancient thali diet: gut microbiota, immunity, and health. Yale J. Biol. Med., 2018, 91, 177-184.

18. Brown, J. M. and Hazen, S., The gut microbial endocrinal organ: bacterially derived signals driving cardio-metabolic diseases. Annu. Rev. Med., 2015, 66, 343-359.

19. Acharya, J. T. (ed.), Charak Samhita with the Ayurved Dipika commentary, Chikitsasthana, Chapter 15, Verse 56, Chaukhamba Krishnadas Academy, Varanasi, 2010, p. 517. 


\section{REVIEW ARTICLES}

20. Acharya, J. T. (ed.), Charak Samhita with the Ayurved Dipika commentary, Chikitsasthana, Chapter 15, Verse 13, Chaukhamba Krishnadas Academy, Varanasi, 2010, p. 513.

21. Jandhyala, S. M., Talukdar, R., Subramanyam, C., Vuyyuru, H., Sasikala, M. and Reddy, D. N., Role of the normal gut microbiota. World J. Gastroenterol., 2015, 21(29), 8787-8803.

22. John, W. P., Metabolism of Steroids and other Lipids, Elsevier's Integrated Review Biochemistry, 2012, vol. 2, pp. 89-98.

23. Hooper, L. V. and Macpherson, A. J., Immune adaptations that maintain homeostasis with the intestinal microbiota. Nature Rev. Immunol., 2010, 10, 159-169.

24. Holzer, P., Reichmann, F. and Farzi, A., Neuropeptide Y, peptide YY and pancreatic polypeptide in the gut-brain axis. Neuropeptides, 2012, 46, 261-274.

25. Kristin, S., Steven, W. M., Olde, D., Martin, von, B., Frank, G. and Schaap, Interactions between bile salts, gut microbiota, and hepatic innate immunity. Immunol. Rev., 2017, 279, 23-35.

26. Acharya, J. T. (ed.), Charak Samhita with the Ayurved Dipika commentary, Vimanasthana, Chapter 5, Verse 7-8, Chaukhamba Krishnadas Academy, Varanasi, 2010, p. 250.

27. Benjamin, J., Marsland, A. T. and Eva, S. G., The gut-lung axis in respiratory disease. Ann. Am. Thorac. Soc., 2015, 12(2), S150-S156.

28. Kamada, N., Chen, G. Y., Inohara, N. and Núñez, G., Control of pathogens and pathobionts by the gut microbiota. Nature Immunol., 2013, 14(7), 685-690.

29. Tlaskalová-Hogenová et al., The role of gut microbiota (commensal bacteria) and the mucosal barrier in the pathogenesis of inflammatory and autoimmune diseases and cancer: contribution of germ-free and gnotobiotic animal models of human diseases. Cell. Mol. Immunol., 2011, 8(2), 110-120; doi:10.1038/cmi. 2010.67.

30. Acharya, J. T. (ed.), Charak Samhita with the Ayurved Dipika commentary, Sutrasthana, Chapter 30, Verse 14, Chaukhamba Krishnadas Academy, Varanasi, 2010, p. 185.

31. Backhed, F., In 99th Dahlem Conference on Infection, Inflammation and Chronic Inflammatory Disorders: The Normal Gut Microbiota in Health and Disease. Clin. Exp. Immunol., 2010, 160, 80-84.

32. Michael, E., Mendelsohn, Richard, H., Karas, The protective effects of estrogen on the cardiovascular system. N. Engl. J. Med., 1999, 340, 1801-1811.

33. Acharya, J. T. (ed.), Charak Samhita with the Ayurved Dipika commentary, Chikitsasthana, Chapter 28, Verse 8-11, Chaukhamba Krishnadas Academy, Varanasi, 2010, p. 617.

34. Chalazonitis, A. et al., Bone morphogenetic protein regulation of enteric neuronal phenotypic diversity: relationship to timing of cell cycle exit. J. Comp. Neurol., 2008, 509, 474-492.

35. Jane, A. F. and Karen, M. N., Gut-brain axis: how the microbiome influences anxiety and depression. Trends Neurosci., 2013, 36(5), 305-312.

36. Ozogul, F., Production of biogenic amines by Morganella morganii, Klebsiella pneumoniae and Hafnia alvei using a rapid HPLC method. Eur. Food Res. Technol., 2004, 219, 465-469.

37. Barrett, E., Ross, R. P., O'Toole, P. W., Fitzgerald, G. F. and Stanton, C., $\gamma$-Aminobutyric acid production by culturable bacteria from the human intestine. J. Appl. Microbiol., 2012, 113, 411-417.

38. Stanaszek, P. M., Snell, J. F. and O’Neill, J. J., Isolation, extraction, and measurement of acetylcholine from Lactobacillus plantarum. Appl. Environ. Microbiol., 1977, 34, 237-239.

39. Acharya, J. T. (ed.), Charak Samhita with the Ayurved Dipika commentary, Chikitsasthana, Chapter 15, Verse 14-16. Chaukhamba Krishnadas Academy, Varanasi, 2010, p. 514.

40. Acharya, J. T. (ed.), Sushruta Samhita, Commentary by Dalhana, Chikitsasthana, Chap. 5, Verse 33, Chaukhambha Sanskrit Sansthan, Varanasi, 2010, p. 424
41. Andrea, T. et al., Aging gut microbiota at the cross-road between nutrition, physical frailty, and sarcopenia: is there a gut-muscle axis. Nutrients, 2017, 1303-1320.

42. De Sire, R. et al., Skeletal muscle-gut axis: emerging mechanisms of sarcopenia for intestinal and extra intestinal diseases. Minerva Gastroenterol. Dietol., 2018, 64(4), 351-362.

43. Acharya, J. T. (ed.), Charak Samhita with the Ayurved Dipika commentary, Sharirasthana, Chapter 2, Verse 4-6, Chaukhamba Krishnadas Academy, Varanasi, 2010, p. 302.

44. Omry, K. et al., Host remodeling of the gut microbiome and metabolic changes during pregnancy. Cell, 2012, 150, 470-480.

45. Baker, J. M., Al-Nakkash, L. and Herbst-Kralovetz, M. M., Estrogen-gut microbiome axis: physiological and clinical implications. Maturitas, 2017, 103, 45-53.

46. Hadar, N., Justine, W. D., Rob, K. and Omry, K., Microbial endocrinology: the interplay between the microbiota and the endocrine system, FEMS Microbiol. Rev., 2015, 39(4), 509-521; https://doi.org/10.1093/femsre/fuu010

47. Gill, S. R., Pop, M., Deboy, R. T., Eckburg, P. B., Turnbaugh, P. J. and Samuel, B. S., Metagenomic analysis of the human distal gut microbiome. Science, 2006, 312(5778), 1355-1359.

48. Roberfroid, M. B., Bornet, F., Bouley, C. and Cummings, J. H., Colonic microflora: nutrition and health. Summary and conclusions of an International Life Sciences Institute (ILSI) [Europe] workshop held in Barcelona, Spain. Nutr. Rev., 1995, 53(5), 127-130.

49. Rakoff-Nahoum, S. and Medzhitov, R., Innate immune recognition of the indigenous microbial flora. Mucosal Immunol., 2008, 1(Suppl 1), S10-S14.

50. Acharya, J. T. (ed.), Charak Samhita with the Ayurved Dipika commentary, Sutrasthana, Chapter 21, Verse 5-27, Chaukhamba Krishnadas Academy, Varanasi, 2010, pp. 116-117.

51. Ley, R. E., Obesity and the human microbiome. Curr. Opin. Gastroenterol., 2010, 26, 5-11.

52. Turnbaugh, P. J., Ley, R. E., Mahowald, M. A., Magrini, V., Mardis, E. R. and Gordon, J. I., An obesity-associated gut microbiome with increased capacity for energy harvest. Nature, 2006, 444(7122), 1027-1031.

53. Othman, A. B., Mazin, A. Z., Ibrahim, T., Jehad, A. and AbuFarha, M., The role of gut microbiota in the development of obesity and diabetes. Lipids Health Dis., 2016, 15(108), 1-8.

54. Paradkar, S. (ed.), Ashtanga Hridayam, Arundatta commentary, Edition 7, Nidanasthana, Chap 10, Verse 7, Chaukhambha orientalia, Varanasi, 1982, p. 503

55. Acharya, J. T. (ed.), Sushruta Samhita, Dalhana commentary, Nidanasthana, Chap. 6, verse 4-5, Chaukhambha Krishnadas Academy, Varanasi, Reprint 2014, 1st edn, p. 290.

56. Paradkar, S. (ed.), Ashtanga Hridayam, Arundatta commentary, Sutrasthana, Chap 11, verse 5, Chaukhambha orientalia, Varanasi, 1982, 7th edn, p. 183.

57. Acharya, J. T. (ed.), Sushruta Samhita, Dalhana commentary, Nidanasthana, Chap 3, verse 21, Chaukhambha Krishnadas Academy, Varanasi, Reprint 2014, 1st edn, p. 279.

58. Tripathi, H. (ed.), Vangasena Samhita, Prameha Rogadhikar, Verse 42, Chaukhambha Sankrit Series, Varanasi, 2009, 1st edn, p. 181.

59. Suresh Babu, M. S. (ed.), Chakradutta, Chap 35, verse 6 \& 59, Chaukhambha Krishna Das Academy, Varanasi, 2012, 1st edn, p. $273,279$.

60. Burcelin, R., Gut microbiota and immune crosstalk in metabolic disease. Mol. Metab., 2016, 5(9), 771-781.

61. Pedersen, H. K. et al., MetaHIT Consortium human gut microbes impact host serum metabolome and insulin sensitivity. Nature, 2016, 535(7612), 376-381.

62. Larsen, N., Vogense, F., Van den Berg, F., Nielsen, D., Andreasen, A. and Pedersen, B., Gut microbiota in human adults with type 2 diabetes differs from non-diabetic adults. PLOS ONE, 2010, 5, e9085, 1-10. 
63. Acharya, J. T. (ed.), Charak Samhita with the Ayurved Dipika commentary, Sutrasthana, Chapter 23, Verse 3-7. Chaukhamba Krishnadas Academy, Varanasi, 2010, p. 122.

64. Marchesi, J. R. et al., The gut microbiota and host health: a new clinical frontier. Gut, 2015, 65, 330-339; doi:10.1136/gutjnl2015-309990.

65. Nicolas, S. et al., Transfer of dysbiotic gut microbiota has beneficial effects on host liver metabolism. Mol. Syst. Biol., 2017, 13(921), 1-17; doi:10.15252/msb.20167356.

66. Acharya, J. T. (ed.), Sushruta Samhita, Dalhana commentary, Uttartantra, Chap 40, verse 139-140, Chaukhambha Krishnadas Academy, Varanasi, Reprint 2014, 1st edn, p. 706.

67. Acharya, J. T. (ed.), Sushruta Samhita. Dalhana commentary. Uttartantra. Chap.43. verse 2-4. Chaukhambha Krishnadas Academy. Varanasi, Reprint 2014, 1st edn, p. 727.

68. Scotti, E. et al., Exploring the microbiome in health and disease: Implications for toxicology. Toxicol. Res. Appl., 2017, 1, 1-37.

69. Bennett, B. J. et al., Trimethylamine- $N$-oxide, a metabolite associated with atherosclerosis exhibits complex genetic and dietary regulation. Cell Metab., 2013, 17, 49-60.

70. Pragman, A. A. et al., The lung microbiome in moderate and severe chronic obstructive pulmonary disease. PLoS ONE, 2012, 7, e47305.

71. Cameron, S. J. et al., Metagenomic sequencing of the chronic obstructive pulmonary disease upper bronchial tract microbiome reveals functional changes associated with disease severity. PLoS ONE, 2016. 11, e0149095.

72. Lad, V., Svoboda, R. E., O'Connor, S., Luna, C. and Curry, K., Textbook of Ayurveda: Volume 1 - Fundamental Principles of Ayurveda, Ayurvedic Press, United States, 2002.

73. Lee, H. U. et al., Host-microbiome interactions: the aryl hydrocarbon receptor and the central nervous system. J. Mol. Med. 2017, 95, 29-39.

74. Rosenfeld, C. S., Microbiome disturbances and autism spectrum disorders. Drug Metab. Dis. Biol. Fate Chem., 2015, 43, $1557-$ 1571.

75. Rodrigues-Amorim, D. et al., The role of the gut microbiota in schizophrenia: current and future perspectives. World J. Biol. Psychiatry, 2018, 1-15.

76. Vogt, N. M. et al., Gut microbiome alterations in Alzheimer's disease. Sci. Rep., 2017, 7(1), 1-11.

77. Winek, K., Dirnagl, U. and Meisel, A., The gut microbiome as therapeutic target in central nervous system diseases: implications for stroke. Neurotherapeutics, 2016, 13, 762-774.

78. Ram Manohar, P., Descriptions and classification of cancer in the classical Ayurvedic texts. Indian J. Hist. Sci., 2015, 50(2), 187-195; doi:10.16943/ijhs/2015/v50i2/48234.

79. Sobhani, I. et al., Microbial dysbiosis in colorectal cancer (CRC) patients. PLoS ONE, 2011, 6(1), e16393.

80. Dias-Jácome, E., Libânio, D., Borges-Canha, M., Galaghar, A and Pimentel-Nunes, P., Gastric microbiota and carcinogenesis: the role of non-Helicobacter pylori bacteria-a systematic review. Rev. Esp. Enferm. Dig., 2016, 108, 530-540.

81. Michaud, D. S. and Izard, J., Microbiota, oral microbiome, and pancreatic cancer. Cancer J., 2014, 20, 203-206.

82. Stojančević, M., Bojić, G., Salami, H. A. and Mikov, M., The influence of intestinal tract and probiotics on the fate of orally administered drugs. Curr. Issues Mol. Biol., 2013, 16(2), 55-68.

83. Patterson, A. D. and Turnbaugh, P. J., Microbial determinants of biochemical individuality and their impact on toxicology and pharmacology. Cell Metab., 2014, 20(5), 761-768.

84. Carding, S., Verbeke, K., Vipond, D. T., Corfe, B. M. and Owen, L. J., Dysbiosis of the gut microbiota in disease. Microbial ecology in health and disease. Microb. Ecol. Health Dis., 2015, 26(1), 1-9.
85. Overvik, E., Lindeskog, P., Midtvedt, T. and Gustafsson, J. A., Mutagen excretion and cytochrome P-450-dependent activity in germfree and conventional rats fed a diet containing fried meat. Food Chem. Toxicol., 1990, 28, 253-261.

86. Gingell, R., Bridges, J. W. and Williams, R. T., The role of the gut flora in the metabolism of prontosil and neoprontosil in the rat. Xenobiotica, 1971, 1(2), 143-156.

87. Noh, K. et al., Impact of gut microbiota on drug metabolism: an update for safe and effective use of drugs. Arch. Pharm. Res., 2017, 1-11.

88. Conly, J. M., Stein, K., Worobetz, L. and Rutledge-Harding, S., The contribution of vitamin K 2 (menaquinones) produced by the intestinal microflora to human nutritional requirements for vitamin K. Am. J. Gastroenterol., 1994, 89(6), 915-923.

89. Lee, S. H., An, J. H., Lee, H. J. and Jung, B. H., Evaluation of pharmacokinetic differences of acetaminophen in pseudo germfree rats. Biopharm. Drug Dispos., 2012, 33, 292-303.

90. Matuskova, Z., Anzenbacherova, E., Vecera, R., TlaskalovaHogenova, H., Kolar, M. and Anzenbacher, P., Administration of a probiotic can change drug pharmacokinetics: effect of $E$. coli Nissle 1917 on amidarone absorption in rats. PLOS ONE, 2014, 9, e87150.

91. Saitta, K. S., Zhang, C., Lee, K. K., Fujimoto, K., Redinbo, M. R. and Boelsterli, U. A., Bacterial beta-glucuronidase inhibition protects mice against enteropathy induced by indomethacin, ketoprofen or diclofenac: mode of action and pharmacokinetics. Xenobiotica, 2014, 44, 28-35.

92. Duda-Chodak, A., Tarko, T., Satora, P. and Sroka, P., Interaction of dietary compounds, especially polyphenols, with the intestinal microbiota: a review. Eur. J. Nutr., 2015, 54, 325-341.

93. Rechner, A. R. et al., Colonic metabolism of dietary polyphenols: influence of structure on microbial fermentation products. Free Radic. Biol. Med., 2004, 36, 212-225.

94. Kim, D.-H., et al., Biotransformation of glycyrrhizin by human intestinal bacteria and its relation to biological activities. Arch. Pharm. Res., 2000, 23(2), 172.

95. Xu, R., Peng, Y., Wang, M., Fan, L. and Li, X., Effects of broadspectrum antibiotics on the metabolism and pharmacokinetics of ginsenoside Rb1: a study on rats gut microflora influenced by lincomycin. J. Ethnopharmacol., 2014, 158, 338-344.

96. Lin, Y. J. et al., Puerariae radix isoflavones and their metabolites inhibit growth and induce apoptosis in breast cancer cells. Biochem. Biophys. Res. Commun., 2009, 378, 683-688.

97. Akao, T. et al., A purgative action of barbaloin is induced by Eubacterium sp. strain BAR, a human intestinal anaerobe, capable of transforming barbaloin to aloe-emodin anthrone. Biol. Pharm. Bull., 1996, 19, 136-138.

98. Jung, M. A. et al., The role of intestinal microflora in antiinflammatory effect of baicalin in mice. Biomol. Ther., 2012, 20, $36-42$.

99. Yang, J. et al., Identification of rutin deglycosylated metabolites produced by human intestinal bacteria using UPLC-Q-TOF/MS. J. Chromatogr. B, 2012, 898, 95-100.

100. Jin, M. J. et al., Effects of gut microflora on pharmacokinetics of hesperidin: a study on non-antibiotic and pseudo-germ-free rats. J. Toxicol. Environ. Health A, 2010, 73, 1441-1450.

101. Jeon, S. M. et al., Hypocholesterolemic and antioxidative effects of naringenin and its two metabolites in high-cholesterol fed rats. Transl. Res., 2007, 149, 15-21.

Received 18 July 2019; revised accepted 25 May 2020

doi: $10.18520 / \mathrm{cs} / \mathrm{v} 119 / \mathrm{i} 3 / 451-461$ 